\title{
DEVELOPMENT STRATEGY OF PEDAGOGICAL COMPETENCE TO IMPROVE PROFESSIONALISM OF ISLAMIC EDUCATION TEACHER
}

\section{Lukman Hakim}

Sekolah Tinggi Hukum (STH) Galunggung

Jl. K. H. Lukmanul Hakim No.17 Tasikmalaya, Jawa Barat, Indonesia 46112

Email: informasi@sthg.ac.id

Received: 07, 2017. Accepted: 12, 2017. Published: 12, 2017.

\begin{abstract}
The purpose of this study is to analyze the pedagogical competence of PAI (Pendidikan Agama Islam/ Islamic education) teachers, the school's strategies to develop PAI teacher's pedagogical competence, the factors that inhibit school strategies, and the evaluation conducted by SMAN 3 (Sekolah Menengah Atas Negeri /Senior High School) 3 Tasikmalaya, Indonesia toward the implementation of the strategies. The research method used is qualitative descriptive which reveals phenomenon holistically and contextually. Data were collected by observation, interview, and documentation. Qualitative descriptive data were analyzed by arranging and classifying the data, thus providing a real picture to the reader. The study conclude that the teachers had already good pedagogical competence, like the ability to understand the diversity of learners, to prepare lesson plans and strategies, to create active, creative, effective, and fun learning, and to evaluate students' learning outcomes. The school had employed strategy to develop PAI teacher's pedagogical competence such as developing teachers regularly every month, involving teachers in various scientific activities, improving the welfare of teachers and educational facilities, supervising, monitoring and evaluating the performance of teachers by providing guidance, giving rewards to outstanding teachers. Thus, the factors inhibited the teachers' pedagogical competence development were two kinds, internal and external factor.
\end{abstract}

Keywords: Competence Pedagogy, Professionalism, Islamic Education.

\section{ABSTRAK}

Makalah ini berisikan analisis kompetensi pedagogik. Guru PAI, strategi sekolah dalam mengembangkan kompetensi pedagogik Guru P AI, faktor penghambat yang mempengarubi strategi pengembangan kompetensi pedagogic, dan evaluasi atas penerapan strategi tersebut terbadap kompetensi pedagogic Guru PAI di SMAN 3 Tasikmalaya, Indonesia. Metode penelitian kualitatif deskriptif digunakan pada penelitian ini untuk mengungkapkan gejala secara holistik dan kontekstual. Data dikumpulkan dengan teknik observasi, wawancara, interview dan dokumentasi. Analisis data secara deskriptif kualitatif dilakukan dengan cara menyusun dan mengelompokkan data yang ada, sehingga memberikan gambaran nyata kepada pembaca. Kesimpulan yang diperoleb dari hasil penelitian ini adalah Guru PAI di SMA Negeri 3 Kota Tasikmalaya sudab memiliki kompetensi pedagogik yang baik, seperti kemampuan memahami keberagaman peserta didik, menyusun rencana dan strategi pembelajaran, menciptakan pembelajaran aktif, kreatif, efektif, dan menyenangkan, dan mengevaluasi hasil belajar peserta didik. Sekolah telah melakukan strategi pengembangan kompetensi Guru PAI dengan cara pembinaan guru secara rutin tiap bulan, mengikutsertakan guru dalam berbagai kegiatan ilmiah, meningkatkan kesejahteraan guru, melengkapi sarana dan prasarana pendidikan, mengawasi, memantau dan mengevaluasi kinerja para pengajar dengan memberikan bimbingan, memberikan penghargaan untuk guru berprestasi. Faktor-faktor penghambat pengembangan kompetensi pedagogik Guru PAI bersifat internal dan eksternal.

Kata Kunci: Kompetensi Pedagogik, Profesionalisme, Pendidikan Agama Islam. 


\section{INTRODUCTION}

Nowadays there is a tendency that teachers have pedagogic competence as a manifestation that they are professional in their fields. The trend shows a reflection of the greater demands of society to the teaching process, the education quality, and their full responsibility despite only teaching and delivering material (Saud, 2009, p. 1). The emergence of these public demands is resulted by the unsure feeling of the teachers toward their profession. There are even some teachers who think that to be a teacher is not a profession, but a semi-profession (Saud, 2009, p. 2). This phenomenon resulted decreasing quality of teachers, and decreasing status of the teachers, which make them doubt about their profession.

The word professionalism and professional in people's daily life have become a common vocabulary. In general, ordinary people use the word professionalism not only in their professional work, but also in every work they have. According to Sagala, professional is when someone can work well, deft, and the results of the work are satisfactory (Sagala, 2000, p. 4).

Being a teacher is actually a professional position. Educational experts have long characterized the teachers work as a profession (Oluremi, 2015). This is also supported by the Law of the Republic of Indonesia No. 14 of 2005 on Teachers and Lecturers, Article 1 which states that: teachers are professional educators with the primary task of educating, teaching, guiding, directing, training, assessing, and evaluating students on the education of children starting from the early age of formal education, elementary education and secondary education ("Law of The Republic of Indonesia, No.14, Teachers and Lecturers," 2005).

Teachers as educators are professionals also stated in the Law on National Education System number 20 of 2003, Chapter XI, Article 29, paragraph 2 that teachers are in charge of planning and implementing the learning process, assessing learning outcomes, providing guidance and training, as well as conducting research and community service, especially for educators at the college ("Law on National Education System, No. 20, Chapter XI, Article 29, paragraph 2," 2003). It fits with the argument of Australian Capital Territory \& Office of Regulatory Services (2014) that the work of lecturers, teachers, and instructors are professional work carried out in a professional manner. Furthermore, Article 8 of the qualifications, competence and certification states that teachers are required to have a pedagogical qualification, competence, educator certificate, physically and mentally healthy and have the ability to achieve national education goals (Astuty, 2015).

One important indicator of teachers' professionalism is that teachers have pedagogic competence (Astuty, 2015). Therefore, the professorship not only requires a specialist teacher in the sense of the ability to master pedagogical knowledge and professional skills that are relevant to their tasks as a teacher, but also the high level of maturity, responsibility and independence.

Teacher is one component of human who has a strategic role in the learning process, especially in developing the quality of human resources. Therefore, teachers as one element of education must play an active role and placing their position as a professional, in accordance with the demands of the growing community. It means every real teacher has a responsibility to bring students to a level of maturity or a certain maturation. In this framework, teachers are not solely as one of the teachers who simply transfer the knowledge, but according to Article 10 paragraph (1), teachers should have pedagogical competence, personal competence, social competence, and professional competence (Astuty, 2015). In education, teachers are educators and mentors who provide direction and guide students in learning (Nawawi, 1999, p. 123).

Teachers will always be an important element that determines the success or failure of education. Therefore, the teachers always play a role in the formation of any potential quality of human resources in the field of development of the nation and state. Teachers are the second person after parents who educate and supervise children to achieve the goals of their life. Thus, 
teachers must have a very high dedication and their chosen profession should not be recognized as secondary job. Teachers determine the success of their learners as the forerunner of a generation who will continue the development especially in Indonesia. The teachers' role in teaching and learning process has very big influence on behavior change of their learners. Due to the effort to change learners' behavior as expected, it needs a professional teacher. It means a teacher who can use the components of education so that the educational process can run well.

On the importance of the teachers' professionalism, the Quran Chapter Al-An'am verse 135 states: Say my people did according full ability, indeed I will do (well). Later you will know who (among us) which will obtain good results from this world (Indonesian Ministry of Religion Affairs, 2014, p. 210)

According to Al Muraghi \& Musofa (2006, p. 128), the verse implies that humans must work according to their abilities and expertise so that they are able to handle the job and to develop all their existing potential for their work personal improvement. They will also always receive guidance from Allah. It means that the teachers' professionalism is very important in the implementation of the learning process and in achieving educational goals. Nowadays, this professionalism has been very important along with the development of science and technology.

Based on the categories of teachers' development, this study is trying to investigate each factors within the categories implemented in SMAN 3 Tasikmalaya, their effort to develop the teachers' pedagogical competence and the evaluation conducted by the school toward their strategies. Therefore, this study also learns more about pedagogical competence development strategies in improving the professionalism of teachers of PAI teachers.

\section{METHOD}

The research used qualitative descriptive method which reveals phenomenon holistically and contextually. The research was conducted in SMAN 3 Tasikmalaya (one of State Senior High School in Indonesia). Data were collected by observation, interview, and documentation. Qualitative descriptive data were analyzed by arranging and classifying the data, thus providing a real picture to the reader.

\section{RESULTS AND DISCUSSION \\ Pedagogical Competence of PAI Teachers in SMAN 3 Tasikmalaya}

There are two models of teachers' professional development that are proposed by UNESCO (Reimers, 2003) and have been implemented in different countries. The first, the model that need and implement certain organizational or institutional partnerships; the second, the model that can be applied on a smaller scale such as a classroom or school. Tabel 1 is the chart summarizing the models included in each category.

PAI teachers in SMAN 3 Tasikmalaya have a fairly good ability in the aspects of pedagogical competence. Pedagogic ability is categorized by the ability of PAI teachers in implementing the learning process, both inside or outside classroom. Among the pedagogical ability of PAI teachers in SMAN 3 Tasikmalaya is the ability of PAI teachers in understanding the diversity of students' abilities, the ability to plan and to use learning strategy, the ability to implement active, innovative, creative, effective, and fun learning as well as the ability to evaluate students' learning outcomes. Thus, PAI teachers in SMAN 3 Tasikmalaya can be said to have been professional because they have been carrying out their profession in accordance with their obligations as teachers. 
Tabel 1. Models of Teachers' Professional Development by UNESCO (Reimers, 2003).

\begin{tabular}{ll}
\hline Organizational partnership models & Small group or individual models \\
\hline Professional-development schools & Supervision: traditional and clinical \\
\hline Other university-school partnerships & Students' performance assessment \\
\hline Other inter-institutional collaborations & Workshops, seminars, courses, etc \\
\hline Schools' networks & Case-based study \\
\hline Teachers' networks & Self-directed development \\
\hline Distance education & Co-operative or collegial development \\
\hline & Observation of excellent practice \\
\hline & Teachers' participation in new roles \\
\hline Skills-development model \\
\hline & Reflective Models \\
\hline & Project-based models \\
\hline & Portofolios \\
\hline & Action research \\
\hline & Use of teachers' narratives \\
\hline & Generational or cascade model \\
\hline
\end{tabular}

PAI teachers' ability to know their students' condition physically, and academically can easily map the overall ability of them. Such capability will allow teachers to give lessons to students by using appropriate teaching methods and appropriate learning media that can be easily understood by their students. This can lead into better students' achievement. This is consistent with Hamalik's opinion (2006, p. 109) that the variety of learners character need to be addressed by educators (parents and teachers) since it will affect the learning outcomes achieved by the students.

In addition, based on the findings, PAI teachers at SMAN 3 Tasikmalaya are also considered to have a good pedagogical ability in terms of their ability in preparing plans and learning strategies. PAI teachers in these schools are already able to understand the characteristics of the subjects. In implementing the learning process, they are able to use the design of the learning process well, although sometimes when there is unpredictable situation the teachers immediately replace the method with other methods in accordance with the existing learning atmosphere. They also use several methods and media that have been provided by the school in the learning process, so that the atmosphere during the process of learning is not monotonous, make students happy and can achieve educational goals.

The importance of PAI teachers to have good ability in implementing the learning strategy is due to two things, namely (1) learning strategy which means a plan of action, including the use of the method and use as a resource in learning and (2) strategies to achieve their certain goals. Dick and Carey (2014) argued that the learning strategy is a learning activity that must be adopted by the teachers so that students can achieve their learning objectives effectively and efficiently. In addition, the learning strategy is a set of instructional materials and procedures which are used to help students to gain their learning outcomes.

In implementing the strategy to develop the teachers' pedagogical competence, teachers can use several methods. They can use expository lecture method, question and answer method or even discussion method by utilizing available resources including the use of instructional media. Therefore, the strategy is different from the method. Strategy refers to a plan to achieve something, while the method is a method that can be used to implement the strategy (Carron, 2010). 
Other pedagogical abilities of PAI teachers in SMAN 3 Tasikmalaya is their ability to implement active, innovative, creative, effective, and fun learning. This was demonstrated by their ability to carry out the teaching and learning process by creating a fun classroom atmosphere, making learners active and creative in explaining subjects. PAI teachers in these schools are not only giving a lecture in front of the class that will only make students understand, but the teachers are also able to create innovative and creative both in word processing, or in using the method. They are able to use some of the strategies or methods that do not make the learners bored, but make the students impressed with a pleasant atmosphere, such as applause and laughter of the students. Thus, the learning atmosphere that teachers create was fun and make students always want to follow the process of learning which greatly assist learners in selflearning process.

PAI teacher's ability to implement active, innovative, creative, effective, and fun learning will be able to streamline the achievement of learning objectives. It is as-stated by Kline (1995), that for most people, learning will be more effective if it is done in a pleasant atmosphere. Everyone is teachers and pupils. Therefore, to create good environment, then the students should develop self-learning process in order to make the students active, creative, effective, and fun or pembelajaran aktif, kreatif, efektif, dan menyenangkan (PAKEM), a meaningful and successful teaching (Nurdin, 2002, p. 26).

Another capability demonstrated by PAI teachers at SMAN 3 Tasikmalaya in relation to the pedagogical competence is the ability to evaluate students' learning outcomes. Based on the findings in the field, PAI teachers at the school in assessing students' learning outcomes use written test, oral examination, active learners, presence, quizzes and assignments, either individuals or groups. Assessment of students' learning outcomes was rated selective because teachers conducted formative assessment at the end of the learning program to see the success rate of learners. Teachers not only assess the final exam of the students, but they started the assessment beginning from the learning process until the final exam as a requirement for learners to be able to go up a class to a higher class.

The phenomenon of PAI teachers in SMAN 3 Tasikmalaya is consistent with Silverius's theory (1991) that explains a good evaluation must be based on learning objectives set by the teacher and are achieved together by teachers and learners. A teacher needs to evaluate the improvement of learners' education. This opinion is also reinforced by Popham \& Baker (2006) that formative assessment is an assessment conducted at the end of the teaching-learning program to see the level of success of the learning process itself. Thus, formative assessmentoriented teaching and learning process with formative assessment is expected to be done by teachers to be able to improve teaching programs and implementation strategies (Sudjana, 2006, p. 5)

\section{School's Strategies in Developing PAI Teachers' Pedagogical Competence.}

The strategies used by the Principal of SMAN 3 Tasikmalaya in developing pedagogical competence in order to improve the professionalism of PAI teachers in school were:

1. Fostering teachers regularly once a month in relation to their mental and career.

2. Undertaking group discussion after office hours.

3. Supporting PAI teachers to attend various seminars and training activities.

4. Supporting PAI teachers to do an action research to improve their teaching quality.

5. Improving the welfare of PAI teachers through periodic salary increases.

6. Improving educational infrastructure so that the education process can run as expected.

7. Supervising, monitoring and evaluating the performance of PAI teachers to provide guidance in the form of academic, administration, and clinical supervision.

8. Giving rewards to the best PAI teachers as well as giving positive appreciation to their accomplishments (Hakim, 2017). 
Among all the practices conducted in SMAN 3 Tasikmalaya, this study only fosters several complete descriptions about the effort to develop teachers' development strategies of pedagogical improvement:

1. Conducting classroom action research.

One of the main strategy conducted by SMAN 3 Tasikmalaya to develop their teachers' quality was by supporting the teachers to do an action research to improve their teaching quality. Classroom Action Research (CAR) is a reflective research conducted by teachers in order to improve their professional competence. CAR is said to be quite effective because it can be done without having to leave the teaching task.

According to Mulyasa (2005, p. 155) CAR has two characteristics. Firstly, it is the issues raised to be resolved and the conditions raised for improvement must depart from actual school practice. Moreover, in CAR, the teacher can ask someone else's help to know and elaborate on the subject matter. In general Mulyasa (2005, p. 155), states that CAR aims to improve the condition and quality of learning in class and to improve professional services in the context of classroom learning, especially services to learners; to provide opportunities for teachers to take action in learning in class; and to provide opportunities for teachers to conduct assessment on learning activities undertaken. Furthermore, the benefits of CAR are to develop and innovate learning; as a curriculum development effort at the class level; and to improve the professionalism of teachers, through research efforts undertaken.

However, there are some general steps that must be considered in developing the design of classroom action research according to Mulyasa (2005, p. 156):

a. Identification of problems;

b. Analyze the problem and determine the various causes factors;

c. Formulate temporary ideas about various important factors related to the problem;

d. Collecting and interpreting data to develop alternative actions;

e. Formulate actions;

f. Assess the outcome of the action.

Kurt Lewin, in his paper "Action Research and Minority Problems" (Lewin, 2010; Mettetal, 2012), described action research as "a comparative research on the conditions and effects of various forms of social action and research leading to social action" that uses "a spiral of steps, each of which is composed of a circle of planning, action, and fact-finding about the result of the action". Action research process embarks on a problem finding, and then formulating possible actions for the problem, applying an action, and finally evaluating on the outcome of the action. These activities go round in a circle. Sometimes, teachers should repeat the process until they can get the desired behaviour.

Action research can be done in any situations, including a classroom. Action research can range from a small-scalled research to a very meticulous one. It can either apply a quantitative or a qualitative approach, or both. The result of the research can be anything (a success or a failure of the action). The methods of gathering data can be as simple as an observation to more complex one like a questionnaire.

In the case of SMAN 3 Tasikmalaya, PAI teachers began to learn to conduct their action research. They did the steps exactly by Mulyasa with some adapted steps regard to the condition in their classroom. This effort seems to be very effective not only to improve their teaching quality but also to improve the intellectual of the teachers.

2. Guiding teachers to develop their pedagogical aspect.

In SMAN 3 Tasikmalaya, the school principal also provides guidance for professional development of teachers' pedagogical aspect in the form of: 
a. Developing teaching profession, such as teaching and coaching preparation, the development of the subject matter, the application of the teaching methodology, the use of media.

b. Helping PAI teachers in their ability to manage the class.

c. Fostering personal and professional attitudes of PAI teachers, especially on the welfare and personal problems of teachers.

d. Developing the quality of teachers' professionalism through: in-service education, and the board of teachers.

According to Wijaya \& Rusiyan (1994, p. 132) guiding is an activity to provide assistance mainly in the form of guidance, supervision and encouragement. All teachers need to get guidance especially the teachers who have not mastered their competence, teachers who have not been able to develop potential possessions, less motivated teachers, and teachers who have not consistent in carrying out its duties. Therefore, it can be concluded that the construction is a series of activities, providing assistance, empowering guidance and motivation useful and successful use in order to improve existing ones forget better results. The form of the construction can be direction, guidance, motivation and performance evaluation teacher by principal. Thus, regarding to the characteristic of guidance explained by the experts, in SMAN 3 Tasikmalaya, the teachers have been guided very well to meet with their pedagogical development needs.

3. Providing supervision.

In SMAN 3 Tasikmalaya, there are two techniques used by the principal to supervise the teachers:

a. Individual technique, which consists of; class visits, classroom observation, personal conversation, class visits and grade self.

b. Group technique, which consists of; orientation meeting for new teachers, teacher meetings, intergroup teacher studies, discussions, seminars, panel discussions, supervision bulletins, and teaching demonstrations.

According to Glickman (1981) and Arni (2005, p. 6) stated that supervision is a series of activities to help teachers develops its ability to manage teaching and learning process for the sake of achievement of teaching objectives. According to Neagley \& Evans (1980, p. 20) education supervision is every service to teachers aiming to make improvements of instructional learning services and curriculum development. According to Sutisna (1983, p. 23) explains that education supervision is the fundamental ideas in promoting the growth of professional teachers, developing democratic leadership, release energy and solve problems learning effectively. From the experts' opinion, it can be suggested that the supervision of education is a series of help, services, and guidance for deep teachers carry out its duties to expand and improve its ability owned.

Based on the discussion above, it can be concluded that the strategy pursued by the principal in developing pedagogical competence of PAI teachers was already well underway by developing some strategies that are considered to be appropriate. As a result, there has been increasing professionalism of PAI teachers in carrying out their duties as educators.

On the principal's role, Sudjana (2006, p. 5) explained that the principal is not only responsible for the administration as described above, but the principal also has duties and responsibilities in the planning process. The principal has to provide guidance, support, supervision and assessment to the teachers during their development strategies implementation. It is important to improve their teaching programs and educational activities in order to create better teaching and learning situation.

According to Sudjana (2006, p. 102), tasks that must be executed by the principal in improving the competence of teachers, among others are: 
a. Guiding the teachers so that they can understand clearly the goals of teaching and the relationship between teaching activities with those goals.

b. Guiding teachers so that they can understand more clearly about the issues and needs of learners, as well as any efforts that can be taken to address and fulfill them.

c. Helping teachers so that they can better understand clearly about the problems and difficulties of learners and what can be done to help and overcome those difficulties.

d. Helping teachers to give them a better teaching skills by using a variety of modern teaching methods in accordance with the subjects given.

e. Selecting and providing tasks that are best suited for each teacher according to students' interests, abilities and talents and to further encourage them to constantly develop their interests, talents and their abilities.

f. Providing wise guidance to teachers, especially to new teachers, so that they can understand and appreciate the atmosphere of the school well.

g. Helping teachers to understand the source of the learning experience for students in the school.

h. Helping teachers to understand, use a variety of teaching tools and improve the quality of learning.

i. Helping teachers to enable them to carry out an evaluation of the results of the progress and growth of learners based on validity and objective.

j. Fostering group's moral.

k. Providing effective leadership and democratic environment for teachers and school staff.

1. Cultivating and developing harmonious relation between members of the school staff and their surrounding community.

Mulyasa (2005) suggests that teacher development can be done by on the job training and in-service training. While Castetter (1996) suggests five models of development for teachers. They are master combined individual, observation or assessment, involvement in a development/improvement process, training and investigation (Sudjana, 2006, p. 103).

Of the five models about teacher development, training is a model of development that is mostly used by private educational institutions. In the educational institutions, a popular way for professional development of teachers is in-service training both in order to refresh and upgrade ability. Other good ways of development for examples are on the job training, workshops, seminars, panel discussions, meetings, symposia, conferences, and so on.

Having analyzed the theory and undertaken observation in SMAN 3 Tasikmalaya, the result shows that the principal's strategy in developing PAI teachers' pedagogical competence to improve their professionalism are mostly compatible with the theory. The principal has tried various efforts to improve the development of PAI teachers' professionalism at the school. The purpose of the pedagogic competence development is to assist the teachers to achieve the education goal. The goals of education are also to enable learners to overcome all the problems they are facing in their lives and to improve the quality of the schools to be recognized in the community as the character building center of the nation.

\section{The Factors Influencing Development Strategy of PAI Teachers' Pedagogical Competence}

The factors affected the application of pedagogical competence development strategies in order to improve the professionalism of PAI teachers in SMAN 3 Tasikmalaya include internal factors such as teachers' enthusiastic, the desire of teachers to develop their knowledge, especially in the aspects of pedagogical competence, and awareness of teachers in facing the global challenges. In the other hand, the external factors are characterized as principal's supervision and adequate facilities. Meanwhile, the factors inhibiting the development of pedagogical strategies to improve the professionalism of PAI teachers in SMAN 3 Tasikmalaya 
include internal factors for example some teachers are less eager to improve their quality, lack of some teachers' understanding on the importance of improving their professionalism. The external factors namely lack of funds.

In that regard, Alma (2008) confirms that due to the lack of professionalism of teachers, among others: 1) there are many teachers who do not pursue the profession as a whole. This is caused by many teachers who have additional work outside working hours to meet the needs of everyday life so they have no time to read and write to improve themselves; 2) some teachers are private college graduates who do not adhere to the ethics of the teaching profession; 3) some teachers have less motivation in improving their quality so that they do not apply what they have gained in their College. Therefore, it can be affirmed that the principal has an important role in implementing the development strategy of pedagogical competence of teachers. A principal can be classified as official leader, formal leader or leader status. A principal who is a leader could increase to become functional leader, or operational leader, depending on their achievement and ability in playing a leadership role in school education (Dirawat, 2013, p. 77).

The principal tasks in the administration areas can be classified into six areas of management namely management of teaching, personnel, discipline, building and courtyard, financial management, and the management of the school and community relations (Dirawat, 2013, p. 80).

In addition to the administrative responsibility for the implementation, the principal also has duties and responsibilities in planning as supervisor. As a supervisor, the principal's task is to provide guidance, support, supervision and assessment related to the implementation and development of technical education. It is conducted to improve their teaching quality.

Based on the principal's tasks, it can be resolved that the true principal should have a strategy to develop the professionalism of teachers in general as described below. There are many ways to develop pedagogical competence of professional teachers, among others are master combined individual; observation or assessment; involvement in a development/improvement process; training; and inquiry (investigation).

Professional development is the study of cooperation by the teachers to the problem and issues that arise during their effort to make their consistent practices with the values of education (Asmani, 2009, p. 81) Among the five development model, training is a model that is mostly used by private educational institutions. In the educational institutions, a popular way for teachers' professional development is in-service training both to refresh and to upgrade their ability. Other good ways of development for examples are on the job training, workshops, seminars, panel discussions, meetings, symposia, conferences, and so on.

Innovation in education has also an impact on teacher development. Some models of teacher development is deliberately designed to deal with educational reform. Candall proposes effective models of professional development of teachers, namely: a model mentoring, applied science models or models from theory to practice, and the model or models of reflective inquiry. Mentoring model is the model in which experienced teachers share the knowledge or perform activities to less experienced teachers. Model applied science research in the form of a combination of products thereof that are relevant to practical needs (Asmani, 2009, p. 81)

Model-based inquiry approach requires teachers to be active researchers by reading, exchanging opinions, undertaking observation, critical analysis, and reflecting on their practical experience. According to Soetjipto \& Kosasi (2004), professional attitude development can be conducted during and after duty.

There are two contributing factors that influence teachers' pedagogical competence development strategy namely internal and external factors. Internal factors that can form and determine the success of the strategy implementation are the teacher pedagogical competence, background of teacher education, teaching experience and mastery of subject matter in depth. 
One of the main requirements that must be met by a teacher or teacher candidates before teaching is to have diploma. As an educator, they should have worthy teaching diploma in an educational institution that has been determined by Teacher Education Development Project (Program Peningkatan Profesionalisme Guru/P3G), Ministry of Education and Culture. with the diploma, teacher has the evidence of teaching experience and a stock of knowledge, both pedagogical and didactic, which has a very important function in assisting the implementation of the tasks of teachers. Without knowing the process in the class, the learning process can be carried out unsuccessfully. This is in accordance with the opinion expressed by Wijaya \& Rusiyan (2004, p. 22) that the level of professionalism of recognition is very dependent on the expertise and level of education taken.

Teaching experience is also a factor which influence the strategy of development of pedagogical competence of teachers. Experience will also support the successful teaching of teachers in performing their duties, because that experience is the best teacher. The longer the teaching experience of teachers, the better they perform their duties.

In addition, the ability to master the subject matter becomes an important indicator in improving the pedagogical competence of teachers. In this case, the teacher must understand well about their material and never teach the material that they do not know. When teachers learn from zero then the quality of teaching will be in jeopardy. Learners feel no satisfaction on teachers' explanation and the knowledge they deliver, or teachers may be lazy and reluctant in explaining the lessons to the students (Saleh, 2005, p. 164).

Other factors affecting the implementation of the development strategy of teacher pedagogical competence is the awareness of teachers to enhance their capabilities. Professional teachers do not just rely on others to develop professionalism. Teachers must have an active mental, dynamic and pro-active in developing potential. They must prepare their lesson well by reading, being active in the discussion and other scientific activities. Teachers should not be preoccupied with teaching, but they must be able to show professionalism in carrying out their functions.

There basic capabilities are in pedagogic, that support the professionalism of teachers, namely planning the teaching program, managing the learning process, assessing the learning process, and mastering the lessons (Saleh, 2005, p. 295). Among the four points, the basic factors that can support the teachers' professionalism is how the teacher can manage and improve matters relating to their duties in a professional manner, so that they can improve the quality of education well.

In addition to internal factors, the external factors also have an influence on the development of teacher competence. External factors that come from outside the teacher which can support or obstruct teachers in performing their duties are: 1) the nature of the characteristics of the child; 2) personnel administration; 3) parents; 4) the family of teachers; 5) professional organizations in the community; and 6) monitoring of principal. (Mulyasa, 2005, p. 49)

Professionalism crisis of teachers in education is problematic for the world of education in creating a good quality. This is due to the lack of awareness of teachers of their task and responsibility. Teachers only considers teaching as an activity to earn a living solely or simply to obtain food and clothing for the sake of salary and short-term physical survival. This is different from the person who see their duties as profession and that what they do is accountable before God (Muhaimin, 2002, p. 118)

There are two important factors that affect the weak attitude of professionalism and work ethic of teachers:

1. Internal factors such as cultural and religious system, the spirit to dig up information and establish communication. 
2. External factors such as historical considerations, including educational background and the natural environment in which the teachers live, sociological or social system in which they lives and other environmental considerations (Saleh, 2005, p. 164)

Mulyasa (2015) revealed some common mistakes made by teachers in learning, namely:

1. Taking shortcuts in learning.

2. Waiting learners to have negative behavior.

3. Ignoring learners' differences.

4. Feeling to be the cleverest.

5. Treating students discriminatively.

Based on these problems, the teacher should be able to understand the conditions that could lead them to make mistake and the most important thing is to control themselves and avoid making mistakes. Some experts have investigated about a "back to basics" reconsideration of teaching and instructional moves. After having aware that even the children from early age or non-schooled people can teach, they considered that teaching lies to "natural cognition" ones. According to Dessus and Mandin (2008), teachers has to do with teaching in the following activities:

1. Monitoring the others' mind (inferring emotions, beliefs, knowledge);

2. Having representations of two levels of knowledge to be taught (i.e., correct knowledge, possible incorrect student's knowledge), as well as having the ability to detect gaps between these two levels of knowledge;

3. Having the ability to communicate knowledge to student (with respect to some important characteristics like its difficulty, level of generality, temporal features);

4. Having the ability to provide feedback (i.e., assessment, corrections) to student.

These four elements would be necessary and sufficient for teaching. Justice in learning is the obligation of teachers and learners must have their rights. In practice, many teachers are unfair, to the detriment of the development of learners and this is a mistake that often being made by teachers, especially in the assessment.

\section{The Evaluation of Teachers' Development Strategy of Pedagogical Competence in SMAN 3 Tasikmalaya.}

In SMAN 3 Tasikmalaya, the evaluation of teachers' development strategy on pedagogical competence has been conducted by the principal in many ways. The principal evaluate from many aspects:

1. The students.

The principal asks the students' satisfaction and review to their teacher performances in the class. They showed the positive feedback toward their teachers' performances. The school has the benefit from the experiences of teachers as well as their knowledge and energy that teachers bring into the classroom. For example, students received the direct assessment from their teachers and their teacher can show them the assessment rubric and result. In the same way Knight (2008, p. 35) found that students increased achievement in their subjects problem solving after implementation of the interventions devised by teachers.

2. The experienced teachers.

The principal review the teachers' performance and also review how the teachers' experience on teaching can support them in teaching and learning activity in the class. Teachers also keep themselves informed of the latest research and theories in teaching because of their connections with the school. In addition, their own professional development is supported as they learn to become mentor teachers and faculty members in school-based programs. There are also reports that teachers and administrators in professional-development schools have a 
very positive attitude towards the schools and their work (Cobb, 2000; Kostin, 1998; Castleman, 1996).

3. The student-teachers.

The principal evaluates the relationship and connectivity between students and teachers. They will implement their knowledge and skills, and have the support of experienced teachers and theory-based knowledge. Many authors have argued that the professional-development schools model has drastically changed the role of student-teachers as they form partnerships with teachers and faculty from the very beginning of their preparation for, and socialization into the profession (Kimball, 1999). In fact, a recent study completed by Beltman et al. (2015) comparing the development of teacher professional identity in pre-service teachers found that the teachers had a more realistic identity, a more systematic and balanced view of the realities of teaching, and a perception of teaching as a 'career' rather than just a job.

4. The school.

The principal also tried to find out the benefit of the development strategies to the school as Larkin said that the school also takes some benefit from this collaborative model (Larkin, 2000). They develop partnerships with practitioners in the field which allow them to be more informed about the daily practices and situations encountered in classrooms, feel supported in their work with student-teachers, and also have the opportunity to link theory and practice more naturally and frequently for a case description (Lemlech, 1977). There are only a few studies in the literature that have examined the impact of professional development schools on university faculty, and more research is clearly needed in this area.

\section{CONCLUSIONS}

After reviewing the theory and analyzing the data on pedagogical competence development strategies in order to improve the professionalism of PAI teachers in SMAN 3 Tasikmalaya, it can be concluded that pedagogical competence of PAI teachers in SMAN 3 Tasikmalaya is fairly good. They are able to make a lesson plan, create a comfortable learning atmosphere, create active learners in the classroom; use multiple methods and media of teaching, understand the diversity of the students' condition, perform the evaluation of learning as well. Moreover, the strategies used in developing the pedagogical competence in order to improve the professionalism of PAI teachers in SMAN 3 Tasikmalaya are by: conducting class visits every month, providing persuasive guidance to teachers, involving teachers in a variety of scientific activities, promoting the welfare of teachers, completing facilities and educational infrastructure, supervising monitoring and evaluating the performance of teachers by providing guidance, giving reward to outstanding teachers and providing educational supervision. Factors that support pedagogical competence development strategies in order to improve the teachers' professionalism include: enthusiastic and outstanding teachers who wish to develop their knowledge, especially in the aspects of pedagogical competence, awareness of teachers to face the global challenges, supervision of principals, and adequate facilities. While the inhibiting factor is that there are several teachers who are less eager to improve their quality and some teachers who are very busy outside the school hours. The evaluation conducted by the principal toward the students, teachers, teacher-student and the school impact showed a positive feedback toward the strategies implementation of teachers' pedagogical development.

\section{BIBLIOGRAPHY}

Alma, B. (2008). Guru profesional menguasai metode dan terampil mengajar. Bandung: Alfabeta. Arni, M. (2000). Komunikasi organisasi. Jakarta: Bumi Aksara.

Asmani, J. M. (2009). Manajemen strategi pendidikan anak usia dini. Jogjakarta: Diva Press. 
Astuty, E. (2015). Implementation analysis of lecturer's pedagogical competence on student's academic achievement. Journal of Management Research, 7(2), 152. https://doi.org/10.5296/jmr.v7i2.6834

Australian Capital Territory, \& Office of Regulatory Services. (2014). The retirement villages handbook: a guide to your rights and responsibilities as a resident, village operator or a prospective resident of a retirement village. Retrieved from https://trove.nla.gov.au/version/206930447

Beltman, S., Glass, C., Dinham, J., Chalk, B., \& Nguyen, B. H. N. (2015). Drawing identity: Beginning pre-service teachers' professional identities. Issues in Educational Research, 25(3), 225-245. Retrieved from http://www.iier.org.au/iier25/beltman.pdf

Carron, G. (2010). Strateguc planning: Technique and methods. Paris: International Institute for Educational Planning. Retrieved from http://unesdoc.unesco.org/images/0018/001897/189759e.pdf

Castetter, W. (1996). The buman research for educational administration. New Jersey: A. Simon \& Schuster Company.

Dessus, P., Mandin, S., \& Zampa, V. (2008). What is teaching? Cognitive-based tutoring principles for the design of a learning environment. In International Conference in Human System Learning (pp. 49-55). Retrieved from https://hal.archives-ouvertes.fr/hal$00308591 /$ document

Dick, W., Carey, L., \& Carey, J. O. (2014). The systematic design of instruction. Pearson Education. Retrieved from https://books.google.co.id/books?id=aSSvAgAAQBAJ

Dirawat. (2013). Pengantar kepemimpinan pendidikan. Surabaya: Usaha Nasional.

Hakim, L. (2017). Observation: developing pedagogical strategies. Tasikmalaya: SMA N 3 Tasikmalaya. Hamalik, O. (2006). Teacher education. Earth Literacy: Jakarta.

Kimball, J. W. (1999). Biologi. Jakarta: Erlangga.

Kline, P. (1995). The everyday genius: Restoring children's natural joy of learning. Arlington, Va: Great River Books.

Knight, G. L. (2008). Issues and alternatives in educational philosophy. Berrien Springs, Michigan: Michigan.

Larkin. (2000). Auditing and profesionalism. Jakarata: PT. Intermasa.

Law of The Republic of Indonesia, No.14, Teachers and Lecturers. (2005).

Law on National Education System, No. 20, Chapter XI, Article 29, paragraph 2. (2003). Ministry of Education.

Lemlech, J. K. (1977). Classroom management. New York: Harper \& Row Publisher.

Lewin, K. (2010). Action research and minority problems (Vol. 2). https://doi.org/10.1111/j.15404560.1946.tb02295.x

Mettetal, G. (2012). The what, why and how of classroom action research. Journal of the Scholarship of Teaching and Learning, 2(1), 6-13. Retrieved from https://goo.gl/mrJGVS

Muhaimin. (2002). Paradigm Islamic education: making efforts Islamic education in schools. Bandung: PT Youth Rosdakarya.

Mulyasa, E. (2005). Become a Professional Teacher. Bandung: YoungRosdakarya.

Muraghi, A. \& Musofa, A. (2006). Translation of tafsir Al-Maraghi. Semarang: Toha Putra.

Nawawi, H. (1999). School organization and management of institutions of class. Jakarta: CV. Haji Masagung.

Neagley, R. L., \& Evans, N. D. (1980). Handbook for effective supervision of instruction. Eng Leys Wood Cliff, New Jersey: Prentce-Hall, inc.

Nurdin, S. (2002). Teachers and curriculum implementation. Jakarta: UIN Shaheed Press. 
Oluremi, F. D. (2015). Professionalization of teaching in Nigeria: Strategies, prospect and challenges. Journal of Education and Learning, 9(3), 190-196. Retrieved from http://journal.uad.ac.id/index.php/EduLearn/article/view/1801/pdf_90

Popham, W. J., \& Baker. (2006). Defining and enhancing formative assessment. In Annual LargeScale Assessment Conference, Council of Chief State School Officers, San Francisco, CA. Retrieved from https://goo.gl/nUw3yJ

Reimers, E. V. (2003). Teacher professional developmrnt: An international review of literature. Paris: International Institute for Education Planning. Retrieved from http://unesdoc.unesco.org/images/0013/001330/133010e.pdf

RI, M. (2014). Qur'an and translation. Jakarta: Ministry of RI.

Sagala, S. (2000). Contemporary educational administration. Bandung: Alfabeta.

Saleh, A. R. (2005). Religious education and character development of the nation. Jakarta: PT. GrafindoPersada.

Saud, U. S. (2009). Teacherprofessional development. Bandung: CV. Alfabeta.

Silverius, S. (1991). Evaluasi hasil belajar dan umpan balik. Jakarta: PT Grasindo.

Soetjipto, \& Kosasi, R. (2004). Profesi keguruan. Jakarta: Rineka Cipta.

Sudjana, N. (2006). Teaching and learning outcomes assessment. Bandung: Young Rosdakarya.

Sutisna, O. (1983). Administrasi pendidikan, dasar teoritis untuk praktek profesional. Bandung: Angkasa.

Wijaya, C., \& Rusiyan, T. (2004). Basic ability teachers in teaching and learning. Bandung: PT. Teens Rosda Offset. 